\title{
Diets and trophic guilds of aquatic insects in Molino River, La Guajira, Colombia
}

\author{
Cristian GRANADOS-MARTÍNEZ, ${ }^{*}$ Bladimir ZÚÑIGA-CÉSPEDES, ${ }^{2}$ Julio ACUÑA-VARGAS ${ }^{1}$
}

${ }^{1}$ Grupo de Investigación EBET, Universidad de la Guajira, Km 5 Vía Maicao, La Guajira, Colombia; ${ }^{2}$ Department of Zoology and Center for Ecology, Southern Illinois University, Carbondale, IL 62901-6501, USA

*Corresponding author: cegranados@uniguajira.edu.co

\begin{abstract}
Aquatic insects are considered a key component for stream food webs because of their contribution to the flow of energy from basal resources to the top predators. For this reason, the study of trophic guilds on aquatic insects is necessary to understand the transformation of energy and matter in stream ecosystems. The study of trophic guilds on aquatic insects has been widely documented in temperate streams. In contrast, little is known about feeding habits and trophic guilds in Neotropical streams. However, several lines of evidence indicate that aquatic insects in the Neotropical region are generally omnivores and that the Fine Particulate Organic Matter (FPOM) is the main food item. To test this hypothesis, we analyzed the diets and the trophic guilds of aquatic insects in an unexplored region of northern Colombia (Molino River, La Guajira). Aquatic insects were sampled using a Surber net, covering the different kind of substrates over a $100 \mathrm{~m}$ reach. Samples were sorted and identified to the lowest taxonomic level possible. We analyzed 250 guts of aquatic insects belonging to six orders, nine families, and 10 genera (Leptonema, Chimarra, Anacroneuria, Nectopsyche, Tabanus, Simulium, Pseudodisersus, Corydalus, Camelobaetidius, and Baetodes). We found that FPOM, algae, and animal tissue were the most important food items in the gut content of the aquatic insects at the Molino River. Our results suggest that aquatic insects in the Molino River are generally detritivores, highlighting the importance of the benthic organic matter in Neotropical streams. We reported-for the first time- the trophic guilds of the genera Nectopsyche and Pseudodisersus, which were categorized as herbivorous. Our results suggest that aquatic insects in the Molino River exploit a variety of food resources and emphasize the importance of the study of feeding habits on aquatic insects in unexplored Neotropical streams.
\end{abstract}

Key words: Aquatic insects; food item; gut content; tropical streams.

Received: March 2015. Accepted: November 2015.

\section{INTRODUCTION}

Aquatic insects have been recognized as an important component in stream food webs constituting the link between food resources (e.g., detritus) and upper trophic levels (e.g., fishes and amphibians) (Wallace et al., 1997; Frauendorf et al., 2013). In this sense, the study of the feeding habits in aquatic insects might explain how matter and energy flow through the food web (Wallace and Webster, 1996). Aquatic insects have shown multiple adaptations to obtain their food resources (Cummins, 1973). The trophic ecology of aquatic insects is divided in two components: feeding behavior and trophic guild (Blondel, 2003). Feeding behavior is based on how they eat the resources and is divided into categories such as shredders, scrapers, and predators. Trophic guild is based on what they eat and is divided into categories such as detritivores, herbivores, and omnivores (Cummins, 1973). Specifically, predators are defined as organisms that eat animal tissue, herbivores as organisms that eat algae and others primary producers, detritivores as organisms that eat benthic organic matter (e.g., leaf litter), and omnivores are organisms that eat both plants and animals (i.e., more than one trophic level) (Simberloff and Dayan, 1991).
Studies about the functional feeding groups (FFGs) of aquatic insects are scarce in the Neotropical region. The published studies have focused on the gut content of macroinvertebrates to describe their functional role in stream food webs (Tomanova et al., 2006; Chará-Serna et al., 2010; Chará-Serna et al., 2012). However, functional feeding groups and trophic guilds have different meanings and we need to complement the study of gut contents with the description of mouthparts and feeding behavior to describe the FFGs in the Neotropical region. The present study is focused on the description of trophic guilds based on gut content in aquatic insects. The indistinct use of FFG and trophic guild concepts might hide our ability to identify general patterns and make reliable comparisons in streams and regions (Ramírez and Gutiérrez-Fonseca, 2014). Although the feeding habits of aquatic insects have been understudied in the Neotropical region, evidence shows that they have a high plasticity with a tendency to the omnivory (Tomanova et al., 2006). For instance, using gut content analysis, Guzmán-Soto and Tamarís-Turizo (2014), studied the feeding habits of immature Ephemeroptera, Plecoptera, and Trichoptera in a Colombian stream (Sierra Nevada de Santa Marta) and found that all genera had at least three food items in their guts 
(e.g. animal tissue, algae, fine particulate organic matter).

In order to test if the aquatic insects of the Molino River (northern Colombia) are generally omnivores, we analyzed the diets and described the trophic guilds (Albariño and Valverde, 1998; Motta and Uieda, 2004; DíazVillanueva and Trochine, 2005; Tomanova et al., 2006; Reynaga, 2009; Boyero et al., 2009). This is the first study of diets and trophic guilds on aquatic insects in La Guajira (northern Colombia), an unexplored area within the understudied Colombian streams. The description of feeding habits of aquatic insects might contribute to the understanding of their role on ecosystem function in tropical streams (Ramírez and Gutiérrez-Fonseca, 2014).

\section{METHODS}

Sampling was conducted in Molino River, a third order stream that flows into Cesar River. Molino River has a length of $27 \mathrm{~km}$ and is located in the south of La GuajiraColombia within the municipality El Molino. The study area $\left(10^{\circ} 38^{\prime} 36.10^{\prime \prime} \mathrm{N}\right.$ and $\left.72^{\circ} 53^{\prime} 57.75^{\prime \prime} \mathrm{W}\right)$ has an elevation of $240 \mathrm{~m}$, which corresponds to the central plain between the Serranía del Perijá and the Sierra Nevada de Santa Marta. The mean annual temperature ranges between $26-34^{\circ} \mathrm{C}$ and the mean annual rainfall ranges between 800 $1000 \mathrm{~mm}$ with rainy (May-June and Aug-Nov) and dry seasons (Dec-Apr). The study site is characterized as a tropical dry forest (Cabrera and Galindo, 2006). The Molino River provides the water supply for the Molino municipality with a mean discharge of $100 \mathrm{~L} / \mathrm{s}$.

Four sampling months were chosen during the dry season (January-April of 2012) using three replicates per microhabitat (riffles, woody debris/snags, sand, undercut bank/root mats, and leaf packs). Aquatic insects were sampled using a Surber net $(250 \mu \mathrm{m}$ of mesh size and 0.09 $\mathrm{m}^{2}$ of area) over a $100 \mathrm{~m}$ reach (each sampling unit corresponds to the Surber net area). Samples were preserved and labeled in Polyethylene bags, with alcohol at 96\%. Aquatic insects were sorted and identified to the lowest possible taxonomic level according to Fernández and Domínguez (2001), Posada-García and Roldán-Pérez (2003), Domínguez et al. (2006), and Domínguez and Fernández (2009). The gut content was analyzed according to Tomanova et al. (2006), where 25 gut contents per taxon were examined and using organisms of relatively similar size. Guts were removed and mounted in polyvinyl alcohol to create semi-permanent slides, which were examined under a microscope (up to $100 \times$ magnification). The gut contents were divided into five food items: i) Fine Particulate Organic Matter (FPOM); ii) Coarse Particulate Organic Matter (CPOM); iii) Microalgae (ALG); iv) Animal Tissue (AT); and v) Fungi (FUNG) (Fig. 1). The mean proportion of each food item (\%) found in each taxon was estimated from the relative area of 20 randomly chosen microscope fields on each slide.

To describe the variation in gut content of the aquatic insects sampled, we performed a principal component analysis (PCA), using the mean percentage of each food item as the variable response. We further used a cluster analysis (Euclidean distance and clustering method) to categorize insect taxa into groups with similar gut contents. To evaluate if the groups formed by the PCA and the cluster analysis were statistically different, we performed a Non-Parametric Multivariate Analysis of Variance (NPMANOVA) using the Bray-Curtis Similarity index. All analyses were performed with PAST software package (Hammer et al., 2001).

\section{RESULTS}

Gut contents of 250 specimens belonging to six orders, nine families, and 10 genera were analyzed. Tab. 1 shows the mean percentage of each food item per taxa where FPOM, ALG, and AT were the main ingested items.

Tab. 1. Mean percentage of the food items in the gut of aquatic insects at Molino River and mean length of the taxa used in the trophic guild categorization.

\begin{tabular}{lcccccccc} 
Order & Taxa & $\mathrm{n}$ & $\mathrm{L}(\mathrm{mm})$ & FUNG & ALG & FPOM & CPOM \\
Diptera & Simulium & 25 & $4.4 \pm 0.8$ & $0 \pm 0$ & $0 \pm 0$ & $100 \pm 0$ & $0 \pm 0$ & $0 \pm 0$ \\
& Tabanus & 25 & $13.8 \pm 1.0$ & $0 \pm 0$ & $0 \pm 0$ & $76.3 \pm 0.6$ & $23.6 \pm 0.6$ & $0 \pm 0$ \\
\hline Trichoptera & Leptonema & 25 & $10.2 \pm 1.0$ & $5.2 \pm 1.2$ & $21.6 \pm 0.4$ & $72.8 \pm 1.6$ & $0 \pm 0$ & $0 \pm 0$ \\
& Nectopsyche & 25 & $8.3 \pm 1.8$ & $0 \pm 0$ & $53.1 \pm 0.8$ & $46.8 \pm 0.8$ & $0 \pm 0$ & $0 \pm 0$ \\
\hline & Chimarra & 25 & $4.9 \pm 0.6$ & $0 \pm 0$ & $0 \pm 0$ & $100 \pm 0$ & $0 \pm 0$ & $0 \pm 0$ \\
Ephemeroptera & Baetodes & 25 & $3.0 \pm 0.2$ & $0 \pm 0$ & $81.9 \pm 3.9$ & $15.2 \pm 9.5$ & $2.7 \pm 5.5$ & $0 \pm 0$ \\
\hline \multirow{2}{*}{ Coleoptera } & Camelobaetidius & 25 & $3.3 \pm 0.5$ & $0 \pm 0$ & $6.0 \pm 1.8$ & $94.0 \pm 1.8$ & $0 \pm 0$ & $0 \pm 0$ \\
\hline Megaloptera & Pseudodisersus & 25 & $4.0 \pm 0.2$ & $0 \pm 0$ & $98.5 \pm 1$ & $1.5 \pm 1$ & $0 \pm 0$ & $0 \pm 0$ \\
Plecoptera & Corydalus & 25 & $15.9 \pm 2.0$ & $0 \pm 0$ & $0 \pm 0$ & $1.5 \pm 1.2$ & $0 \pm 0$ & $98.5 \pm 1.2$ \\
\hline
\end{tabular}

L, length, FUNG, fungi; ALG, microalgae; FPOM, fine particulate organic matter; CPOM, coarse particulate organic matter; AT, animal tissue. Values are mean $\pm S D$. 
Specifically, Simulium and Chimarra ingested exclusively FPOM, Baetodes and Pseudodisersus ingested mainly ALG, and Corydalus and Anacroneuria ingested mainly AT. From PCA results is possible to identify three groups of taxa according to their affinity to food items (Fig. 2). The first two axes of the PCA plot explained $98 \%$ of the total variance. The gradient on the first axis was explained by FPOM (eigenvector: -0.798 ) which was correlated to Camelobaetidius, Chimarra, Simulium, Tabanus, and Leptonema, whereas the gradient on the second axis was explained by ALG (eigenvector: 0.746) which was correlated to Nectopsyche, Pseudodisersus, and Baetodes, and AT (eigenvector: 0.660) which was correlated to Corydalus and Anacroneuria.

Figs. 3 and 4 show the three main dietary groups (IIII) identified with the cluster analysis and the mean percentage of food items per each trophic guild, respectively. Group I contained two taxa (Anacroneuria and Corydalus) with an average of $85 \%$ of AT in their guts and categorized as predators. Additionally, FPOM was also an important food item in this group. Group II included three taxa (Nectopsyche, Pseudodisersus, and Baetodes) with an average of $80 \%$ of ALG in their gut content and categorized as herbivorous. Group III contained five taxa: Leptonema, Tabanus, Simulium, Chimarra, and Camelobaetidius. This group had an average of $89 \%$ of FPOM in their guts and was categorized as detritivores. The PCA and the cluster analysis showed matching results where the same taxa were grouped within each food item
(Figs. 2 and 3), confirming the trophic guild categorization. Likewise, there were statistically significant differences in gut content between the trophic guilds identified by the PCA and the cluster analysis (i.e., detritivores, herbivorous, and predators: NPMANOVA, $\mathrm{P}<0.01$ ).

\section{DISCUSSION}

The most important food item for the aquatic insects in the Molino River was FPOM, which was presented in all trophic guilds. Our results are similar to other studies in the Neotropical region, where many insect taxa are categorized as detritivores (Palmer et al., 1993; Tomanova et al., 2006; Reynaga, 2009; Chará-Serna et al., 2010; Guzmán-Soto and Tamarís-Turizo, 2014). Several lines of evidence support that detritus is a common resource in tropical streams (Tomanova et al., 2006; Chará-Serna et al., 2010; Guzmán-Soto and Tamarís-Turizo, 2014). benthic organic matter inputs (e.g., leaf litter) occur throughout the year, in contrast to temperate streams with seasonal leaf fall (autumn). This means that CPOM is generally available and the physical (e.g., discharge) and biological (e.g., shredders) fragmentation to FPOM might be a general process in tropical streams (Dudgeon, 1982; Covich, 1988; Mathuriau and Chauvet, 2002; Dobson et al., 2002). Based on the results of the present study, the presence of FPOM in the gut content of aquatic insects might explain the ubiquity of this food resource in tropical streams (Allan et al., 1987; Henriques-Oliveira et al., 2003).
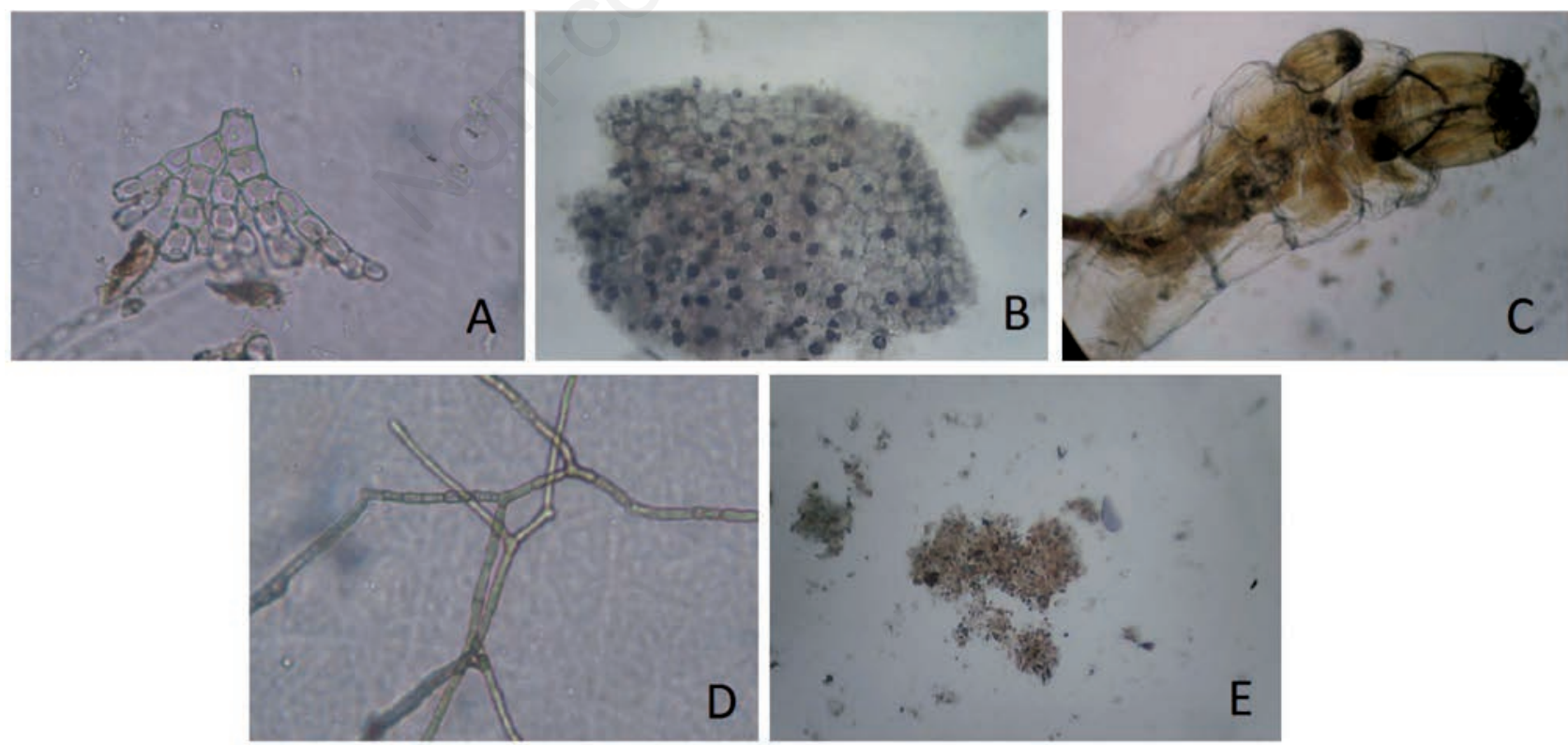

Fig. 1. A). Microalgae (ALG) in the gut of Baetodes (40×). B). Coarse particulate organic matter (CPOM) in the gut of Tabanus $(10 \times)$. C). Animal tissue (AT), (Chironomidae larvae) in the gut of Anacroneuria (10×). D). Fungi (FUNG) in the gut of Leptonema (10×). E). Fine particulate organic matter (FPOM) in the gut of Camelobaetidius $(10 \times)$. 


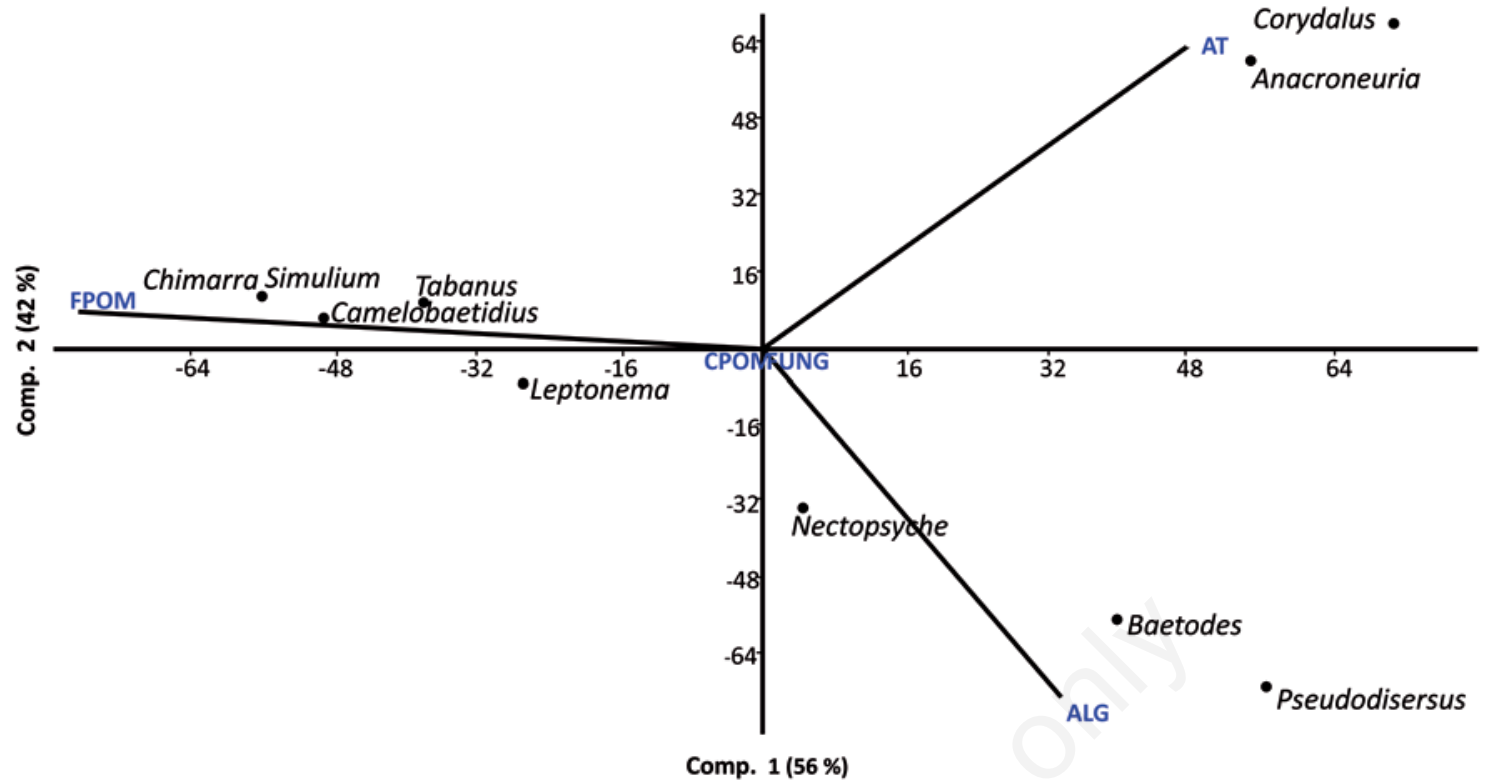

Fig. 2. Principal component analysis (PCA) of ten genera of aquatic insects grouped on the basis of the gut content in Molino River.

\section{Similarity}

i i i i i $i$ i

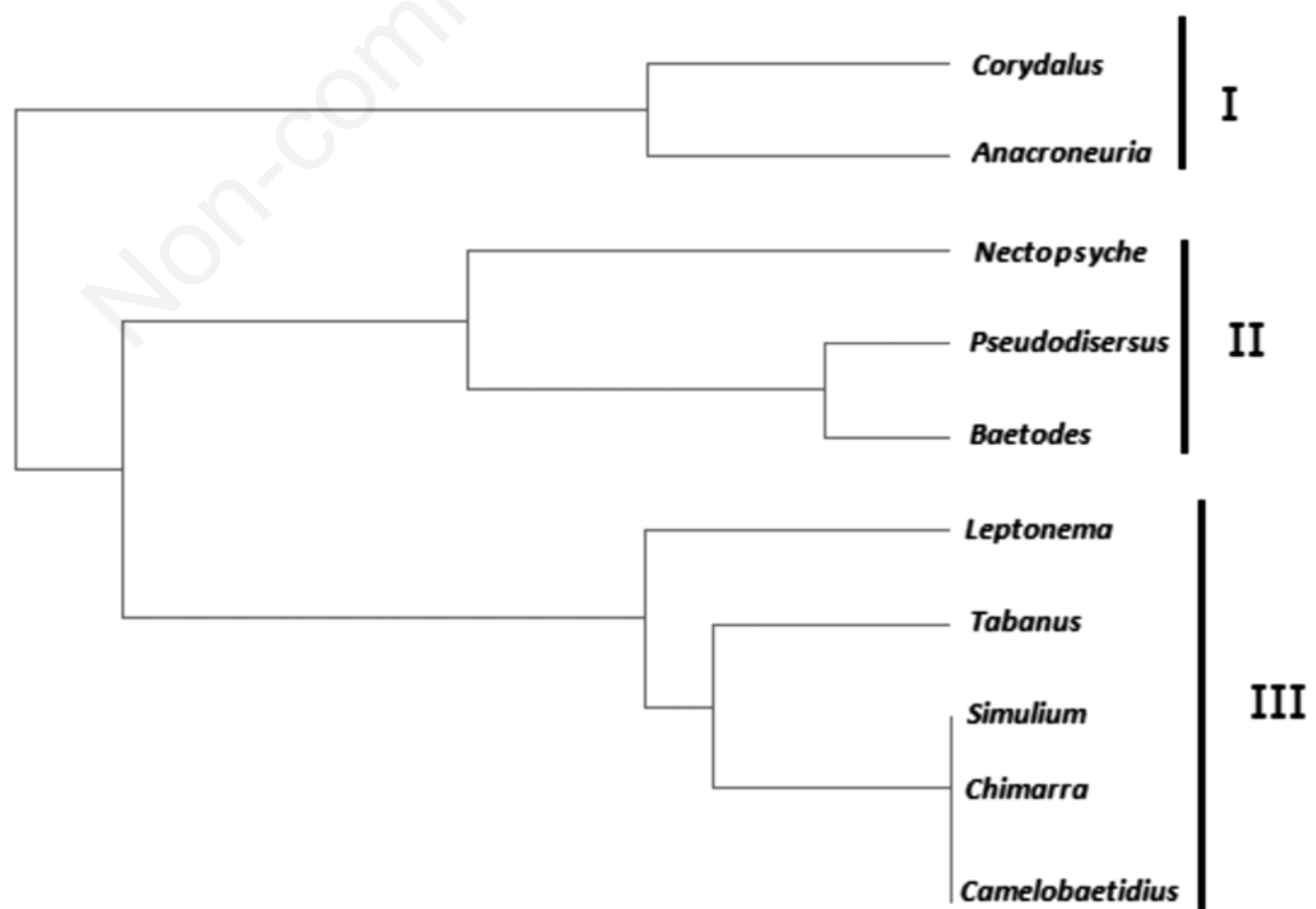

Fig. 3. Cluster analysis of ten genera of aquatic insects, based on proportions of food items founded in their guts. Three groups were identified: I, Predators; II, Herbivorous; III, Detritivores. 
Three trophic guilds were identified in the aquatic insects studied in the Molino River (predators, detritivores, and herbivores). We found contrasting results in the trophic guild categorization of insect genera at the Molino River, when comparing with studies in temperate and tropical streams. For instance, we found similar results in the categorization of Corydalus and Anacroneuria, which have been described as predators (Tomanova et al., 2006; Tamarís-Turizo et al., 2007; Domínguez and Fernández, 2009; Chará-Serna et al., 2010; Guzmán-Soto and Tamarís-Turizo, 2014) However, early instars of Anacroneuria has been described as detritivores (Merritt et al., 2008). We found FPOM in the gut content of Anacroneuria, though we are unable to identify if the FPOM is the result of insect digestion or the gut content of their prey. On the other hand, Leptonema has been categorized as an omnivore in temperate streams (Merritt et al., 2008), which contrasts with this study where they are categorized as detritivores and supports the results obtained by Guzmán-Soto and Tamarís-Turizo (2014). Nonetheless, Leptonema had ALG and FUNG in its gut content, so we cannot discard it as an omnivore and further studies are necessary to validate our results. Leptonema is part of the Hydropsychidae family (Trichoptera), filter feeders that use nets to build refuges and passively capture potential food particles (Ramírez and Gutiérrez-Fonseca, 2014). The gut content of this family includes a wide range of food resources, including animal prey in larger species (Benke and Wallace, 1980).

In our study, Chimarra had only FPOM in its gut content and was categorized as a detritivore, which supports the results by Guzmán-Soto and Tamarís-Turizo (2014). Camelobaetidius was categorized as detritivore with a high percentage of FPOM and a low content of ALG in its gut. This result is relatively similar to the reported by Tomanova et al. (2006), which found FPOM and microphytes in the gut content. Tabanus was considered a detritivore in the present study, contrasting with previous studies which categorized it as a predator (Merritt et al., 2008; Chara-Serna et al., 2010). This result supports the hypothesis that Tabanus might be an opportunistic feeder, but more studies are necessary in order to confirm our results. In the present study, the food items in the gut content of Nectopsyche were ALG and FPOM, in accordance to the reported by Merritt et al. (2008). We did not find published information about the trophic guild of Nectopsyche in the Neotropical region. However, in terms of the FFG, several studies have described the Nectopsyche species as shredders in both temperate (Walters et al., 2007) and tropical streams (Graça et al., 2001). Our study mainly categorized Pseudodisersus as herbivorous, constituting the first report of the trophic guild for this Neotropical

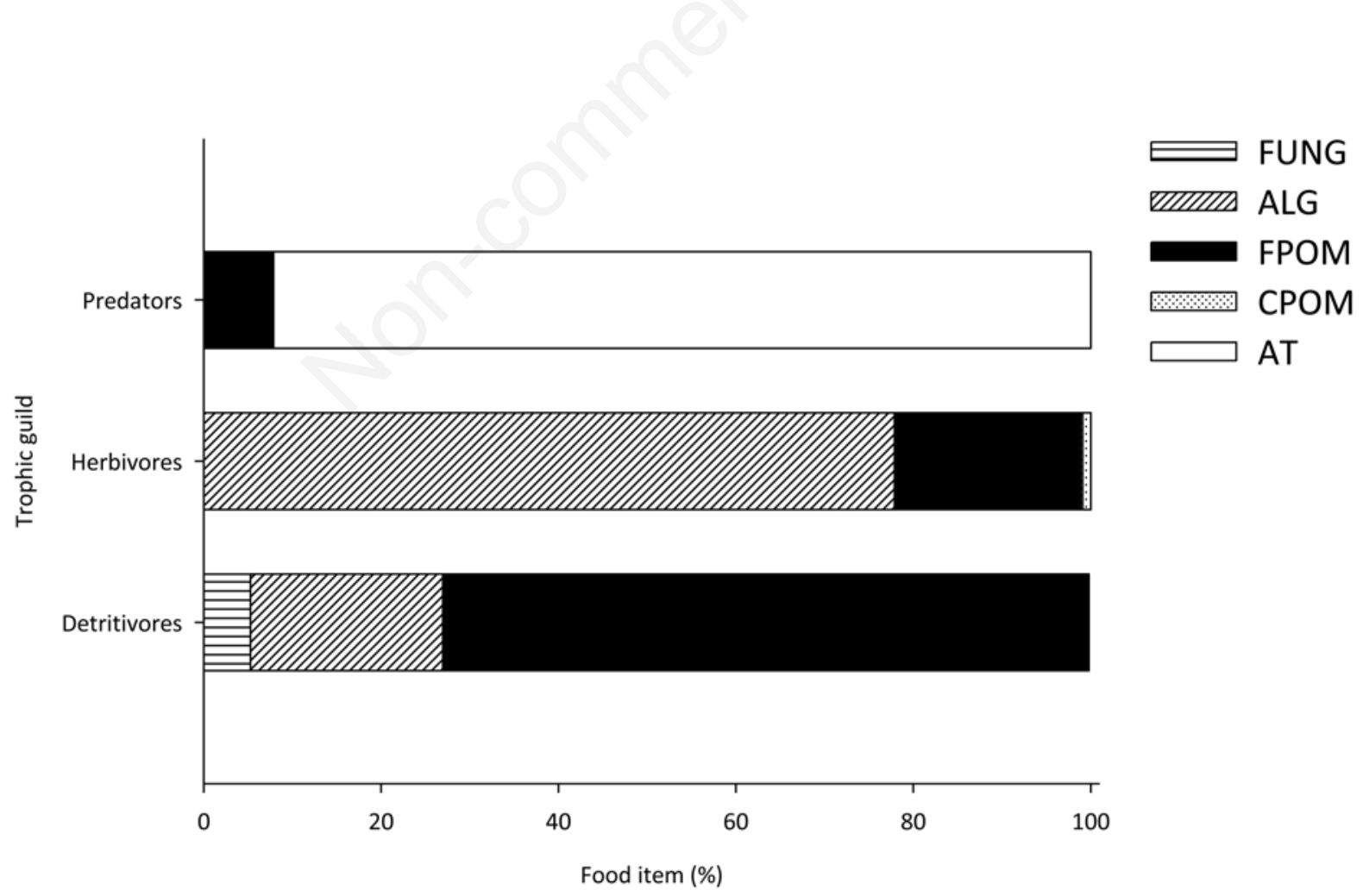

Fig. 4. Mean percentages of the food items ingested by each trophic guild of the aquatic insects at the Molino River. The trophic guilds derived from the cluster analysis. FPOM, fine particulate organic matter; CPOM, coarse particulate organic matter; ALG, microalgae; AT, animal tissue; FUNG, fungi. 
genus (Spangler and Santiago-Fragoso, 1987). Additionally, our results support the reports of other studies that categorized Baetodes as herbivorous (Baptista et al., 2006; Merritt et al., 2008).

\section{CONCLUSIONS}

The FPOM was the main food item in aquatic insects of the Molino River (La Guajira, Colombia). This study highlights the importance of detritus as a permanent food resource and as a key component of the food webs in Neotropical streams. Most taxa ingested at least two food items, except Simulium and Chimarra. Our study showed that aquatic insects in the Molino River are mainly detritivores, which does not support the hypothesis that omnivory is a common characteristic in the Neotropical region. The present study describes the trophic guilds of the genera Nectopsyche and Pseudodisersus for the first time and constitutes the first report for La Guajira (northern Colombia). The study of feeding habits and trophic guilds in aquatic insects is important to understand their functional role and relevancy in the conservation of the Neotropical streams.

\section{ACKNOWLEDGMENTS}

We thank Universidad de La Guajira (Colombia) for the financial and logistic support through the Facultad de Ciencias Básicas y Aplicadas, the Department of Biology, and the Research Center. We are grateful to three anonymous reviewers for valuable suggestions during the development of this manuscript. B.Z.C. is sponsored by a Fulbright-Colciencias grant.

\section{REFERENCES}

Albariño RJ, Valverde A, 1998. [Hábito alimenticio del estado larval de Parasericostoma cristatum (Trichoptera: Sericostomatidae)].[Article in Spanish]. Rev. Soc. Entomol. Argent. 57:131-135.

Allan JD, Flecker AS, McClintock NL, 1987. Prey preference of stoneflies: sedentary vs mobile prey. Oikos 49:323-331.

Baptista DF, Buss DF, Dias LG, Nessimian JL, Da Silva ER, De Moraes Neto AHA, de Carvalho SN, De Oliveira MA, Andrade LR, 2006. Functional feeding groups of Brazilian Ephemeroptera nymphs: ultrastructure of mouthparts. Ann. Limnol. 42:87-96.

Benke AC, Wallace JB, 1980. Trophic basis of production among net-spinning caddisflies in a southern Appalachian stream. Ecology 6:108-118.

Blondel J, 2003. Guilds or functional groups: does it matter? Oikos 100:223-231.

Boyero L, Ramirez A, Dudgeon D, Pearson RG, 2009. Are tropical streams really different? J. N. Am. Benthol. Soc. 28:397-403.

Cabrera E, Galindo GA, 2006. [Aproximación metodológica para la delimitación de ecosistemas de enclaves secos. Caso piloto: Cañones del río Dagua y del río Tuluá, Valle del Cauca - Colombia].[Book in Spanish]. Instituto de Investigación de Recursos Biológicos Alexander von Humboldt,
Bogotá: 45 pp.

Chará-Serna AM, Chará JD, Zúñiga MdC, Pedraza GX, Giraldo LP, 2010. [Clasificación trófica de insectos acuáticos en ocho quebradas protegidas de la ecorregión cafetera Colombiana].[Article in Spanish]. Univ. Sci. 15:27-36.

Chará-Serna AM, Chará JD, Zúñiga MdC, Pearson RG, Boyero L, 2012. Diets of leaf litter-associated invertebrates in three tropical streams. Ann. Limnol. 48:139-144.

Covich AP, 1988. Geographical and historical comparisons of Neotropical streams: biotic diversity and detrital processing in highly variable habitats. J. N. Am. Benthol. Soc. 7:361-386.

Cummins KW, 1973. Trophic relations of aquatic insects. Annu. Rev. Entomol. 18:183-206.

Díaz-Villanueva V, Trochine C, 2005. The role of microorganisms in the diet of Verger cf. Limnophilus (Trichoptera: Limnephilidae) larvae in a Patagonian Andean temporary pond. Wetlands 25:473-479.

Dobson M, Magana A, Mathooko JM, Ndegwa FK, 2002. Detritivores in Kenyan highland streams: more evidence for the paucity of shredders in the tropics? Freshwater Biol. 47:909-919.

Domínguez E, Fernández R, 2009.[Macroinvertebrados bentónicos sudamericanos: sistemática y biología].[Book in Spanish]. Fundación Miguel Lillo, Tucumán: 656 pp.

Domínguez E, Molineri C, Pescador M, Hubbard M, Nieto C, 2006. Ephemeroptera of South America. Aquatic Biodiversity of Latin America. 2. Pensoft, Sofia-Moscow: 646 pp.

Dudgeon D, 1982. The life history of Brotia hainanensis (Brot, 1872) (Gastropoda: Prosobranchia: Thiaridae) in a tropical forest stream. Zool. J. Linn. Soc. 76:141-154.

Fernández H, Domínguez E, 2001. [Guía para la determinación de los artrópodos bentónicos sudamericanos].[Book in Spanish]. Universidad Nacional de Tucumán: 282 pp.

Frauendorf TC, Colón-Gaud C, Whiles MR, Barnum TR, Lips KR, Pringle CM, Kilham SS, 2013. Energy flow and the trophic basis of macroinvertebrate and amphibian production in a Neotropical stream food web. Freshwater Biol. 58:1340-1352.

Graça MAS, Cressa C, Gessner MO, Feio MJ, Callies KA, Barrios C, 2001. Food quality, feeding preferences, survival and growth of shredders from temperate and tropical streams. Freshwater Biol. 46:947-957.

Guzmán-Soto CJ, Tamarís-Turizo CE, 2014. [Hábitos alimentarios de individuos inmaduros de Ephemeroptera, Plecoptera y Trichoptera en la parte media de un río tropical de montaña].[Article in Spanish]. Rev. Biol. Trop. 62:169-178.

Hammer Ø, Harper DAT, Ryan PD, 2001. PAST: Paleontological Statistics Software Package for Education and Data Analysis. Palaeontologia Electronica 4:1-9.

Henriques-Oliveira AL, Nessimian JL, Dorville LFM, 2003. Feeding habits of chironomid larvae (Insecta: Diptera) from a stream in the Floresta da Tijuca, Rio de Janeiro, Brazil. Rev. Bras. Biol. 63:269-281.

Hynes HB, 1970. The ecology of running waters. University of Toronto Press: 555 pp.

Mathuriau C, Chauvet E, 2002. Breakdown of leaf litter. J. N. Am. Benthol. Soc. 21:384-396.

Merritt RW, Cummins KW, Berg MB, 2008. An introduction to the aquatic insects of North America. Kendall/Hunt Publishin, Dubuque: 1214 pp. 
Motta RL, Uieda VS, 2004. Diet and trophic groups of an aquatic insect community in a tropical stream. Braz. J. Biol. 64:809-817.

Palmer C, O'Keeffe J, Palmer A, Dunne T, Radloff S, 1993. Macroinvertebrate functional feeding groups in the middle and lower reaches of the Buffalo River Eastern Cape, South Africa. I. Dietary variability. Freshwater Biol. 29:441-453.

Posada-García GJ, Roldán-Pérez G, 2003. [Clave ilustrada y diversidad de larvas de Trichoptera en el Noroccidente de Colombia].[Article in Spanish]. Caldasia 25:169-192.

Ramírez A, Gutiérrez-Fonseca PE, 2014. Functional feeding groups of aquatic insect families in Latin America. Revista de Biología Tropical. 62(Suppl2):155-167. Rev. Biol. Trop. 62:9-20.

Reynaga MC, 2009. [Hábitos alimentarios de larvas de Trichoptera (Insecta) de una cuenca subtropical].[Article in Spanish]. Ecol. Austral. 19:207-214.

Simberloff D, Dayan T, 1991. The guild concept and the structure of ecological communities. Annu. Rev. Ecol. Evol. Syst. 22:115-143.
Spangler PJ, Santiago-Fragoso S, 1987. A revision of the Neotropical aquatic beetle genera Disersus, Pseudodisersus, and Potamophilops (Coleoptera: Elmidae). Smithsonian Institution Press: 40 pp.

Tamarís-Turizo C, Turizo-Correa R, Zúñiga MdC, 2007. [Distribución espacio-temporal y hábitos alimentarios de ninfas de Anacroneuria (Insecta: Plecoptera: Perlidae) en el río Gaira (SNSM, Colombia)].[Article in Spanish]. Caldasia 29:375-385.

Tomanova S, Goitia E, Helešic J, 2006. Trophic levels and functional feeding groups of macroinvertebrates in Neotropical streams. Hydrobiologia 556:251-264.

Wallace JB, Webster JR, 1996. The role of macroinvertebrates in stream ecosystem function. Ann. Rev. Entomol. 41:115-139.

Wallace JB, Eggert SL, Meyer JL, Webster JR, 1997. Multiple trophic levels of a forest stream linked to terrestrial litter inputs. Science 277:102-104.

Walters DM, Fritz KM, Phillips DL, 2007. Reach-scale geomorphology affects organic matter and consumer $\delta 13 \mathrm{C}$ in a forested Piedmont stream. Freshwater Biol. 52:1105-1119. 